\title{
Determination of nursing students' self-efficacy belief levels in anatomy lectures
}

\author{
Rabia Tasdemir ${ }^{\text {1a }}$, Ismail Sivri ${ }^{1}$, Dilsat Güzelordu ${ }^{1}$, Mehmet Deniz Yener $^{1}$, Elif Aksu ${ }^{1}$, \\ Serap Colak ${ }^{2}$, Belgin Bamac ${ }^{1}$, and Tuncay Colak $^{1}$ \\ ${ }^{1}$ Kocaeli University, School of Medicine, Department of Anatomy, Kocaeli, Turkey \\ ${ }^{2}$ Kocaeli University, School of Physical Education and Sport, Department of Sports Management, \\ Kocaeli, Turkey
}

\begin{abstract}
The Anatomy is the most basic lecture of the departments that give health education. The human anatomy is need to be comprehended to success in nursing field. Anatomy subjects are taught independently in each committee in Nursing Department that is in School of Health in Kocaeli University. The aim of our study is assessment of the impact of the Anatomy lectures on Anatomy Self-Efficacy Beliefs of nursing students. Totally 95 students (mean of ages $19,13 \pm 1,595)$ who are 25 boys $(\% 26,3)$ and 70 girls $(\% 73,7)$ attended to our research. Anatomy Self-Efficacy Belief (ASEB) scale and personal information survey(age, gender, the geographical region that he/she came from, the place that he/she resides) are applied to these students. Statistically, when the relation between ASEB levels of the students and their residences was assessed, it is found that there is a significant difference on between the ASEB levels of the students who reside in dormitory and that of the students who reside at home $(p<0.05)$. This outcome makes think that the residences of students can be effective on their success levels on the lectures. Due to the fact that dormitories that are in campus are close to the university, the attendances of lectures of students who reside in dormitory are more than the others and it shows that these students are able to study better than the others.
\end{abstract}

Keywords: Anatomy, self-efficacy, nursing, education

\section{Introduction}

Anatomy is one of the basic lectures of health education providing departments. In order to be successful in nursing carrier, human anatomy must be well understood. In Kocaeli University School of Health nursing department, anatomy lectures are being taught systembased curricula in which learning is integrated in each tract and independently between different tracts. The purpose of our study is to determine the nursing student's self-efficacy

a Corresponding author: rabia.tasdemir@kocaeli.edu.tr 
belief levels in anatomy lectures which are being taught according to the system-based curricula.

Bandura [3] had described the term "self-efficacy" as one's ability to cope with the problems that one has came across in personal life or professional life. Self-efficacy, which is a concept developed by social psychology, can be performed in many different fields according to the needs.

When a person encounters a problem, both in daily life and in education life; actions that are necessary to solve the problem are how well implemented shows the individual's level of self-efficacy. In other words, self-efficacy expresses individual's ability to perform and succeed in a task.

According to the studies published by Colak [5] and Zimmerman [11], self-efficacy belief scale is one of the significant parameters which can be used in the education field. In the departments which provide health education, studies related to education although recently increased, we had encountered studies about self-efficacy published by only Lök [8] and Taşdemir [10].

\section{Method}

95 nursing students studying in 1st grade had been participated in our study. A survey of personal information (age, sex, geographic region it came, the place of residence) and anatomy training self-efficacy beliefs scale was applied to the students who participated.

Research data source is data collection survey and ASEB scale. The reliability of survey questionnaire is related to consistency of measuring, repetable and balanced [6]. Related to this, self-efficiancy for anatomy is prepared as articles, asked to professionals if they were relevant. Content validity confirmed by specialists' opinion and named as ASEB scale. Anatomy self-efficacy beliefs scale (ASEB) had been prepared adapting the scale which had been created by Akkoyunlu and his colleagues [1] and Colak [5] with anatomy containing 15 items of propositions. Responses had been settled by five-point Likert-type scale and the degree of participation to each instruction had been classified as 1 stating "strongly disagree", 2 "disagree", 3 "undecided", 4 "agree" and 5 "completely agree" [6]. Statistical analysis of the data collected had been made using SPSS 18.0 for Windows software package.

\section{Results}

25 male $(\% 26,3), 70$ female $(\% 73,7)$ in the total of 95 (mean age: 19,3 $\pm 1,595)$ 1st grade nursing students had been participated in our research (table 1). Analyzed by gender, average ASEB levels of male students had been found $46.04 \pm 9.195$, and the average ASEB levels of female students $48.01 \pm$ is 3,724. Statistically, there was no significant difference between the students' ASEB levels according to their gender and the geographic region they came from $(\mathrm{p}>0.05)$ (Table 1$)$.

Table 1. Nursing students' distributions by gender and ASEB averages.

\begin{tabular}{lccc}
\hline Gender & $\begin{array}{c}\text { Average ASEB }(\bar{x}) \\
\text { Male }\end{array}$ & $\begin{array}{c}\text { Standard } \\
\text { Deviation }\end{array}$ & P Value \\
\hline $\begin{array}{l}\text { 25 kişi }(\% 26,3) \\
\text { Female }\end{array}$ & 46,04 & 9,195 & \\
$70(\% 73,7)$ & 48,01 & 3,724 & 0,517 \\
Total & 47,49 & 5,703 & \\
$95(\% 100,0)$ & & & \\
\hline
\end{tabular}


In accordance with the information obtained, the bond between the geographic regions students came from and their ASEB levels had been evaluated. Most participation is from the Marmara region with the number of 61 students $(\% 64,2)$. Black Sea Region is in the second rank with the percentage of 10,5 which is respectively followed by Southeastern Anatolia Region consisting 7 students $(\% 7,4)$; East Anatolia and Central Anatolia each consisting 6 students $(\% 6,3)$ and 3 foreign nationals $(\% 3,3)$. Least participation is from Aegean and Mediterranean regions each containing only 1 student $(\% 1,1)$ (Table 2$)$

Table 2. The distribution of the nursing student's number and ASEB averages according to the geographic region they came from.

\begin{tabular}{|c|c|c|c|}
\hline Regions & Average ASEB $(\boldsymbol{x})$ & Standard Deviation & P Value \\
\hline $\begin{array}{l}\text { Mediterranean } \\
1 \text { person }(\% 1,1)\end{array}$ & 49,00 & 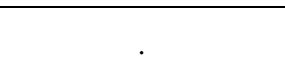 & \multirow{9}{*}{0,126} \\
\hline $\begin{array}{l}\text { East Anatolia } \\
6 \text { people }(\% 56,3)\end{array}$ & 50,50 & 5,320 & \\
\hline $\begin{array}{l}\text { Aegean } \\
1 \text { person }(\% 1,1)\end{array}$ & 50,00 & . & \\
\hline $\begin{array}{l}\text { Southeastern Anatolia } \\
7 \text { people }(\% 7,4)\end{array}$ & 42,14 & 13,813 & \\
\hline $\begin{array}{l}\text { Central Anatolia } \\
6 \text { people }(\% 6,3)\end{array}$ & 49,33 & 3,141 & \\
\hline $\begin{array}{l}\text { Black Sea } \\
10 \text { people }(\% 10,5)\end{array}$ & 50,90 & 4,280 & \\
\hline $\begin{array}{l}\text { Marmara } \\
61 \text { people }(\% 64,2)\end{array}$ & 47,16 & 4,286 & \\
\hline $\begin{array}{l}\text { Abroad } \\
3 \text { people }(\% 3,2)\end{array}$ & 46,00 & 1,414 & \\
\hline Total 95 people $(\% 100,0)$ & 47,49 & 5,703 & \\
\hline
\end{tabular}

ASEB levels compared according to the geographic regions students came from, the ones from the Black Sea region have the highest ASEB levels with $50.9 \pm 4.28$. The second highest ASEB level belongs to the ones coming from Eastern Anatolia Region with $50,5 \pm 5,32$. The foreign nationals are in the last row according to their ASEB levels with the score of 41 (Table 2)

Table 3. Distribution of nursing students' number and average ASEB levels according to their place of habitation.

\begin{tabular}{lccc}
\hline Place of habitation & Average ASEB $(\bar{x})$ & Standard Deviation & P Value \\
\hline Home & 46,12 & 4,669 & \\
33 kişi (\%34,7) & 48,23 & & 0,008 \\
Dormitory & & 6,093 & \\
62 kişi (\%65,3) & 47,49 & 5,703 & \\
Total & & & \\
\hline 5 kişi (\%100,0) & & & \\
\hline
\end{tabular}

When evaluated according to their place of habitation statistically significant difference has been found between the average ASEB levels of 33 students living in dormitories $(34.7 \%)$ and 62 students living at home $(65.3 \%)(\mathrm{p}<0,05)$ (Table 3$)$.

\section{Discussion}

When the data questionnaire applied in our study is evaluated, it has been found that parameters such as gender, age and the geographic region the students came from has no effect on the ASEB levels. Although ASEB levels of the female students had been found 
higher than the male students, there was no statistically significant difference $(p>0,05)$. When the ASEB values between geographical regions are evaluated, it has found that students coming from the Black Sea Region have the highest ASEB values but still no significant difference was detected $(\mathrm{p}>0,05)$.

Another parameter our data survey contained was the determination and comparison of ASEB levels according to the sheltering circumstances of the college students. As a result of our assessment when ASEB levels or compared between staying at home or in a dormitory, a significant difference was found as an increase for the ones staying in a dormitory $(\mathrm{p}<0,05)$.

There are many studies searching for the effects of sheltering circumstances on the college students. Arl1 [2] had searched for the effects of different sheltering places on the college students' personal, social developments and academic successes and said that staying in a dormitory, living away from their families has a positive effect on the aspects mentioned above. We think that this positive effect has increased the ASEB levels of the students staying in a dormitory.

On the other hand Kaya E. and his colleagues had searched the effects of the negativities caused by the classroom environment and sheltering problems on the students' success. The researcher identified that dormitory environment prevents students from studying and the absence of a study room of their own effects their academic successes. On the contrary it can be said that students staying in a dormitory are more successful in anatomy education considering the ASEB levels in our study.

We have encountered some researches like our ASEB survey in which a life satisfaction questionnaire had been applied to the college students living in a house or a dormitory. Özgür and his colleagues [9] had investigated the life satisfaction levels of students staying in a house or in a dormitory and identified that the students staying in a house have higher levels of life satisfaction compared to the ones staying in a dormitory. This has shown us the comfort of staying in a house and having a room of their own have a positive effect on the students' life satisfaction levels. But the data obtained in our study doesn't support this situation.

The success levels of the anatomy lectures in faculties and schools providing health care education will allow health care providers to perform more efficient by knowing the human body better while practicing their professions. In our study, we identified anatomy lectures' self-efficacy belief levels to examine the anatomy knowledge of nursing students. With reference to that we identified the students' success levels can be effected in terms of sheltering circumstances both in anatomy and in other lectures.

\section{References}

1. Akkoyunlu, B., Orhan F. Bilgisayar ve Öğretim Teknolojileri Eğitimi (BÖTE) Bölümü Öğrencilerinin Bilgisayar Kullanma Öz Yeterlik İnancı ile Demografik Özellikleri Arasındaki İlişki. Turk. Online J. Educ. Technol. 2 (3), 8693 (2003).

2. Arl, E. Review of the Effects of Housing Place on Individual and Social Development and Academic Success of University Students by Focus Group Discussion. Journal of Higher Education and Science. 3 (2), 173-178 (2013).

3. Bandura, A. Selfefficacy: Toward a unifying theory of behaviour change. Psychol. Rev. 84, 191-215 (1977).

4. Bozdoğan, A.E., Öztürk, Ç. Coğrafya İle İlişkili Fen Konularının Öğretimine Yönelik ÖzYeterlilik İnanç Ölçeğinin Geliştirilmesi. Necatibey Eğit. Fak. Elektronik Fen ve Mat. Ĕgit. Dergisi. 2(2), 66-81 (2008). 
5. Çolak, S. The Relationship among Computer SelfEfficacy Scores, Demographic Charecteristics and Grades in Computer Courses of Students at the School of Physical Education and Sports. Educational Research and Reviews. 8(8), 374-377 (2013).

6. Erdoğan, İrfan. SPSS Kullanım Örnekleriyle Araştırma Dizaynı ve İstatistik Yöntemleri. Ankara: Emel. (1998).

7. Kaya, E. et al. The Effects of Negativities from Class Circumstances and Residence to Student's Success. Erzincan Eğitim Fakültesi Dergisi. 7(2), 41-51 (2005)

8. Lök, S., Taşğın, Ö., Lök, N., Yıldız, M. Karamanoğlu Mehmet Bey Üniversitesi Farklı Bölüm Öğrencilerinin Anatomi Dersine Olan ÖzYeterlilik Durumlarının Karşılaştırılması. Selçuk Üni. Sosyal Bil. Ens. Dergisi. 21, 339-345 (2009).

9. Özgür, G., Gümüş, A.B., Durdu, B. Life Satisfaction of University Students Living at Home or in the Dormitory. Journal of Psychiatric Nurses. 1(1), 25-32 (2010).

10. Taşdemir, R. et al. The Comparıson of Self-Efficacy Belıefs of Anatomy between The First And The Second Class Students in Medical School. TOJET: the Turkish online journal of educational technology. Special issue 2 for INTE 2015, 570-574 (2015).

11. Zimmerman, B.J. SelfEfficacy: An Essential Motive to Learn. Contemporary Educational Psychology. 25, 82-91 (2000). 